\title{
Teorias/teses nativas e arqueológicas sobre os Geoglifos no
}

\section{Acre}

\section{Native and archaeological theories/thesis about the geoglyphs in the State of Acre, Brazil}

\author{
Enviado em: 14/01/2017 \\ Aceito em: 14/01/2017 \\ BELTRÃO, Jane Felipe ${ }^{1}$ \\ LOPES, Rhuan Carlos dos Santo ${ }^{2}$
}

\begin{abstract}
Resumo:
Discutir a partir de teorias/teses nativas e arqueológicas sobre os geoglifos, no Acre, a relação estabelecida entre comunidade e pesquisadores quando da realização de trabalhos em Arqueologia Comunitária, trazendo à tona os conhecimentos tradicionais como possibilidade de articulação entre a "ciência do concreto" e as formulações acadêmicas, mediadas pelo registro etnográfico que pode conjugar esforços na preservação do patrimônio arqueológico sem que seja necessário apartar os moradores do sítio arqueológico.
\end{abstract}

Palavras-chave: Geoglifos. Arqueologia Comunitária. Registros etnográficos.

\begin{abstract}
This article seeks to debate, from the native and archaeological theories/theses, about the geoglyphs in the state of Acre, Brazil. The relationship established between the community and researchers when carrying out Community Archaeology work, bringing out traditional knowledge as a possible link between the "science of the concrete" and academic formulations, mediated by the ethnographic record that can join forces to preserve archaeological heritage without having to separate the residents from an archaeological site.
\end{abstract}

Keywords: Geoglyphs. Community Archaeology. Ethnographic records.

Debater a relação entre comunidades e pesquisadores é sempre um desafio. Especialmente quando a proposta é realizar o trabalho em conjunto para que os resultados possam de alguma maneira beneficiar os primeiros. Essa tem sido a

\footnotetext{
1 Antropóloga, historiadora, docente dos programas de pós-graduação em Antropologia e Direito da Universidade Federal do Pará (UFPA). Bolsista de produtividade em pesquisa do Conselho Nacional de Desenvolvimento Científico e Tecnológico (CNPq). Endereço eletrônico: janebeltrao@gmail.com.

${ }^{2}$ Arqueólogo, doutorando no Programa de Pós-Graduação em Antropologia, na Universidade Federal do Pará (PPGA/UFPA). Bolsista CAPES. Endereço eletrônico: rhuan.c.lopes@gmail.com.
} 
principal característica da Arqueologia Comunitária, dedicada ao esforço de envolver populações locais tanto nas pesquisas arqueológicas, quanto nas políticas de patrimônio cultural (FERREIRA, 2008). Como bem indicou Hodder (1994), dialogar com as vozes locais implica em exercer arqueologia indagadora sobre a relação estreita entre pessoas e seus passados. Assim, a cultura material tem o particular potencial para evocar memórias, sentimentos e construir narrativas (JACQUES, 2013).

$\mathrm{Na}$ verdade, a abstrata conversão dos espaços comunitários em sítios arqueológicos, definidos a partir de convenções científicas como limites para intervenção arqueológica (DUNNELL, 1992), implica em confronto epistemológico, ensejado pela distância ou aproximação das categorias nativas e arqueológicas (CABRAL \& SALDANHA, 2008; GOMES \& LOPES, 2012; SCHAAN \& MARQUES, 2012). Na fronteira desse contato, a arqueologia, em especial na Amazônia, tem com frequência incorporado pressupostos colonialistas ao subestimar o público e seu conhecimento acerca do patrimônio arqueológico (SCHAAN, 2011). Em se tratando desta região, diferentes trabalhos acadêmicos têm provocado inflexão sobre a prática denunciada por Schaan, resultando em reflexões substanciais ao desenvolvimento epistemológico da arqueologia, particularmente no que diz respeito ao trato à diversidade de representações sobre o registro arqueológico (BEZERRA, 2011; CABRAL, 2014; CABRAL \& SALDANHA, 2008; FERNANDES, 2014; GOMES \& LOPES, 2012; LEITE, 2014; MORAES, 2012). Nessas investigações, ficam evidentes as necessárias negociações de identidades que dizem respeito à relação entre arqueologia e comunidades (FERREIRA, 2008).

Tendo isto em vista, no artigo debatemos o processo de Musealização do Geoglifo Tequinho no Acre, projeto coordenado por Denise Pahl Schaan. Construídos nos solos da Amazônia oriental, os geoglifos consistem em grandes estruturas de terra, construídas em diferentes formas geométricas por grupos humanos organizados regionalmente (SCHAAN et al., 2007). As diferentes figuras sugerem que os locais eram destinados ao exercício cosmológico e religioso de seus construtores. Morfologicamente, "são formadas por um conjunto de valeta e mureta adjacente, esta última formada pelo solo escavado e depositado do lado de fora da valeta", que por sua vez possuem em média $10 \mathrm{~m}$ de vão, com profundidade que varia entre $1 \mathrm{e} 7 \mathrm{~m}$ (SCHAAN et al., 2007, p. 74). Em termos geográficos atuais, os geoglifos estão distribuídos desde o leste do Acre ao oeste de Rondônia, estendendo-se ao norte da Bolívia ao sul do Amazonas, indicando a apropriação desse tipo de arquitetura por 
diferentes grupos étnicos, detentores de saberes matemáticos e de engenharia acurados (SCHAAN, 2010).

Na década de 70, do século XX, no bojo das pesquisas do Programa Nacional de Pesquisas Arqueológicas na Bacia Amazônica (PRONAPABA), as estruturas em terra começaram a ser descritas, mas somente partir de 1999 começaram a ser amplamente conhecidas pelo público e por arqueólogos brasileiros (SCHAAN et al., 2007). Atualmente, somam-se 415 recintos geométricos registrados somente no estado do Acre, sendo um deles o Tequinho, sobre o qual pretende-se executar o projeto de musealização.

Figura 1: Geoglifo Tequinho, no Acre.

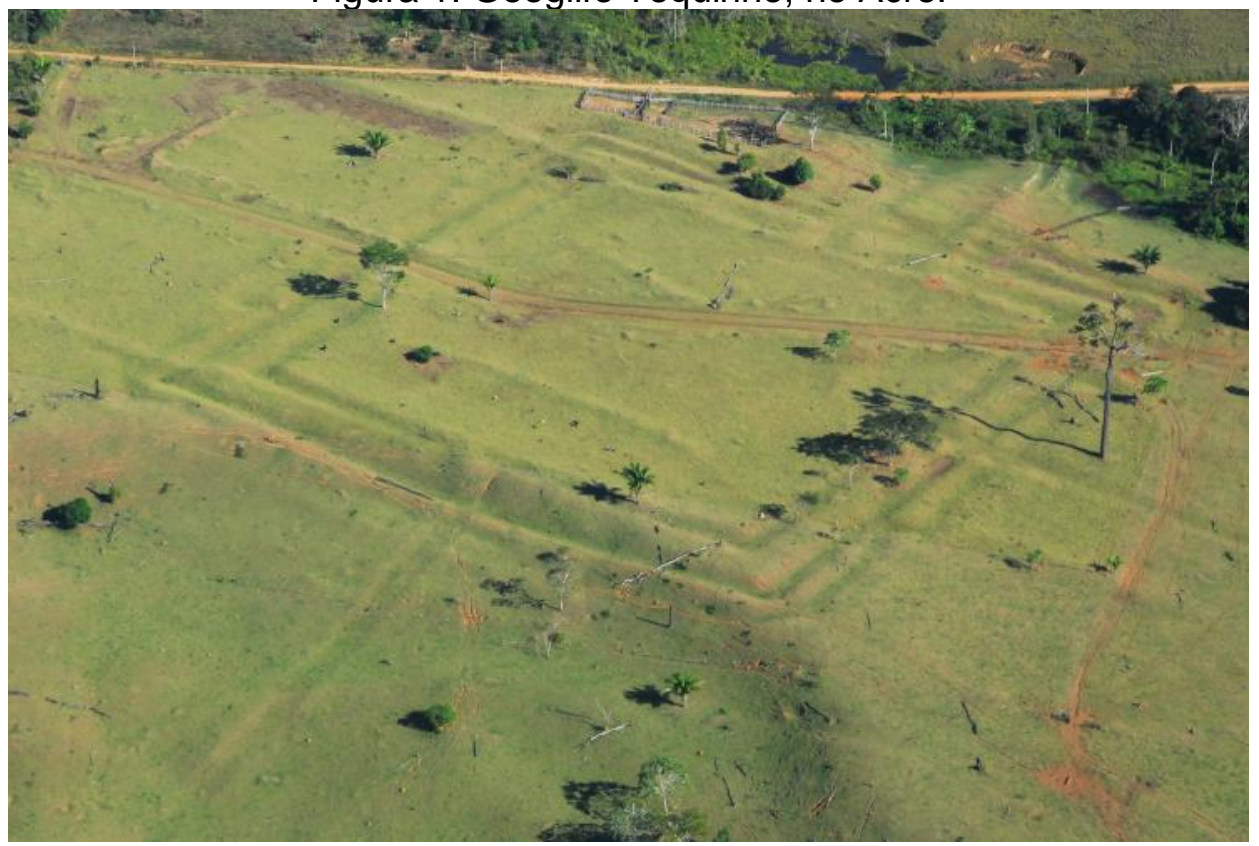

Foto: Edison Caetano (2008).

Para execução deste projeto, as estratégias de Arqueologia Comunitária são utilizadas de modo a manter interface com as comunidades locais. Como indica Ferreira (2008, p. 87), parte da metodologia no desenvolvimento desta arqueologia, diz respeito às entrevistas e pesquisas em história oral com os moradores locais, no intuito de permitir entendimento de seus "sentimentos e interpretações", ao passo em que analisam-se as negociações e experimentações desses sujeitos frente ao patrimônio cultural oriundo das escavações. Assim, para realizar trabalhos em conjunto com os moradores, os pesquisadores interagem com a comunidade em todas 
as etapas do projeto e, sobretudo, devem ouvir e compreender as relações que as pessoas mantêm com os sítios arqueológicos.

Neste texto, referimos as histórias, as "teorias das avós" sobre o que são os geoglifos e, particularmente, o que se diz sobre o Tequinho. Na sequência, mostra-se como os arqueólogos trabalham e podem utilizar as histórias ouvidas para formular hipóteses de interpretação do material que identificaram, recolheram e analisaram, é dessa forma que se aponta a colaboração necessária à execução de propostas de Arqueologia Comunitária.

\section{Mil e uma Histórias... sem fim}

Em 2012, no contexto do Projeto de Musealização do Geoglífo Tequinho Arqueologia comunitária no Acre, Rio Branco foi o destino para conhecer e interagir com as pessoas que "fazem" o trabalho no local. Da capital ao Tequinho convivendo com moradores, conversamos com professores e estudantes da área, onde se projeta um "museu a céu aberto", o qual possa ser apropriado e encaminhado pelos interessados na preservação da História local. Por lá a escuta das histórias foi produtiva e interessante. Agora, pedimos licença para contá-las. Como diz a canção, “... [n]ão canto pra enganar, vou pegar minha viola ...", ${ }^{3}$ no caso, pega-se o lápis, aciona-se a memória, relembramos os momentos, e se inicia a narração das histórias, compartilhando com os leitores os "mistérios" guardados nos geoglifos.

Desta maneira, mais pessoas podem lembrar-se de histórias interessantes e assim aumentar o conhecimento sobre o Tequinho as quais poderão ser ouvidas pelos visitantes ao chegarem ao espaço ou quando os moradores resolverem trocar ideias em noite de lua, à soleira das portas, "jogando conversa fora".

Nas escolas Capitão Edgar Cerqueira Filho, União e Progresso e São Francisco de Assis II, no entorno do geoglifo Tequinho, foram ouvidas as narrativas feitas por professores e estudantes, pois o trabalho de arqueologia comunitária é feito considerando a formação de pessoas que valorizem os bens patrimoniais locais. A reprodução das mesmas, associadas aos desenhos produzidos pelos estudantes, pode informar às novas gerações sobre o assunto que, na sequência, passam a conhecer e, mais adiante, podem até monitorar/guiar as visitas ao espaço do Tequinho, contando aos que chegam as histórias que muitos conhecem. Como disse

\footnotetext{
${ }^{3}$ Cf. Vandré, Geraldo \& Barros, Theo de. Disparada. http://letras.mus.br/geraldo-vandre/46166/. Acesso em 15. jan. 2014.
} 
Estela, ${ }^{4}$ professora na Vila Pia, "já estou imaginando... [e olhando na direção do Tequinho completa] os visitantes do mundo inteiro chegando para conhecer os sítios e um pouco mais do Acre e da cultura dos povos amazônicos."

As histórias, como quer Estella, nos ajudam a conhecer o mundo dos antigos e os nossos antepassados, além de nos situarem no presente valorizando o patrimônio do lugar e apresentando aos demais um pouco do muito que se construiu e se constrói planejando o futuro (CHOQUE QUISPE, 2007).

\title{
Eram engenheiros... e muitos...
}

Nas conversas com o senhor Joaquim, ele contou: "eu cheguei aqui em 1948, vim pro Acre porque ia ser seringueiro. Andei por essas terras... ninguém, uma imensidão sem fim. Floresta naquela época era mata virgem, só tinha estrada de seringueiro." Era campina e seringal, de resto "nos vivia tudo na escravidão da borracha [sistema de aviamento]. Daí, depois, vieram, apareceram os fazendeiros que passavam e, em dois dias, "tacavam fogo" e queimavam tudo pra "botar pasto", era a pata do boi que invadia o Acre."

Um dia, lá por 1966,

\begin{abstract}
fui brocar [preparar o terreno para agricultura] e descobri esse negócio, essa terra grande, cercada de "valos" fundos. Pensei ao ver os buracos quando vier a chuva vai virar um açude! Fiquei assuntando, olhando de longe. Veio a chuva e nada de encher, o "valo" fica todo tempo seco, a gente só escutava um barulho, uma soada, assim, fina como vento soprando, parece até coisa sobrenatural, pois buraco comum enche d'água, transborda! O fato leva a pensar: para onde vai a água da chuva.
\end{abstract}

E Joaquim prossegue, "matutando... pensei: trincheira não é porque é passageira [temporária], só existe na guerra depois some, acaba. Aqui, a guerra foi contra os bolivianos, assim se fez o Acre, faz muito tempo! Portanto... parece trincheira!"

Os desenhos ficam no meio da plantação, mas penso, narra Joaquim, que "não é coisa de soldado de guerra, também não é de soldado da borracha, a gente não precisava de trincheira. É coisa de engenheiro (construtor), camarada inteligente, pois a mata era toda igual e ele fez em cima da ribanceira." E, pelo tamanho dos desenhos de terra produzidos,

\footnotetext{
${ }^{4}$ Para resguardar a identidade dos generosos interlocutores, os nomes referidos no texto são fictícios e qualquer semelhança com a realidade é mera coincidência.
} 
tinha muito ajudante na construção, eram muitas pessoas. E, veja bem, não tinha máquina... Agora, para se ver assim... bonito... tudo em caminho de "valo", eu só vi depois das fotografias, pois é só de cima que se pode ver. Camarada inteligente quem fez, só pode ser engenheiro! Eu não sei fazer. Deve ter dado muito trabalho, imagina! Eles não tinham carro de mão, é "tudinho" feito no braço, no muque, não tinha máquina não.

Muita gente acha que é trincheira e que durante a guerra entre acreanos e bolivianos, as valas serviam para se esconder dos inimigos do lado de cá dos combates, pois abrigava da chuva, não acumulava água. Achei "sem querer", por acaso, informa Joaquim,

Eu derrubei (desmatei), depois da "descoberta", muita gente vem, e um tanto de gente vai lá nos geoglifos. É rede de televisão, fotógrafo, balão voando, helicóptero, muito movimento, até demais. Vieram uns "cabras" [homens] lá de Cruzeiro do Sul (AC), depois que saiu na revista, a matéria tinha causado grande "admiração", surpresa mesmo! Ninguém acreditava, tinha que ver para crer. Muitos ligam (por telefone) pra saber se é verdade.

\section{São cabralinos...}

O senhor Sandro, nordestino de Alagoas, narrou que no local - município de Senador Guiomard (AC) - "no passado era só espinho e sapé, e ele trabalhando "matou tudo de ruim" e plantou." Olhando para sua casa, informou que no local, existia apenas um barraquinho, e ele não foi o primeiro morador do lote, antes umas três famílias tinham passado por lá, ele comprou o terreno em 1983. Disse Sandro:

As "valas" que vocês andam atrás, [olhando para os interlocutores a sua frente] eu não conhecia, não. Não calculava nada, mas como não corre água no local, porque tudo é muito plano pra fazer "valeta". Daí, eu curioso... andei por todo lado, dentro delas só pra calcular o tamanho, pois é grande. E, assim, eu percebi que a "terra" dentro das "valetas" era quadrada, "desenhadinha" com terra.

Assim prossegue o narrador, "me veio a ideia que era do tempo do Acre contra a Bolívia, dos dias da guerra, mas eu mesmo 'desmanchei' [abandonei] a ideia. Vi que não podia ser." Prossegue o senhor Sandro, em animada conversa, disse:

há lugares em que as "valetas" medem 1,20 m de profundidade e uns 0,80 $\mathrm{cm}$ de largura, daí pensei... tem soldado magro, mas tem uns que são bem fortões, daqueles que os botões da farda quase estoura, eles não iam caber dentro da "valeta" escavada [construída por alguém], portanto, é sem condição de ser da guerra.

Pensar assim, diz Sandro, "é não ter noção do que é uma trincheira." 
Foi assim, andando e pesquisando que descobri o assunto, as versões são muitas e se espalham pelos lugares. Muitos contam, outros escutam as várias histórias. A versão cabralina diz que as "valetas" foram feitas antes de Cabral $^{5}$ chegar ao Brasil, portanto os "quadrados" de terra rodeados e protegidos pelas ditas "valetas" são pré-cabralinos, ou seja, "indígenas".

Mas, continua o senhor Sandro, "não sei pra que servia. Hoje, fica aí no meio da fazenda e, quem conta, sempre aumenta um conto, pois acrescenta o que sabe ou ouviu dizer."

\title{
Serão chineses? Sei não!
}

Há quem diga que os geoglifos foram feitos por chineses para trabalhar com petróleo, desde a Bolívia, segundo o senhor Manuel. Entretanto, asseverou "eles podem ser sabidos como for, mas se fosse mesmo petróleo as valas eram perfuradas e canalizadas [recobertas] com camada de bronze, pois por elas passaria o produto. E, até onde se sabe, não há marcas de petróleo."

Uma vez, noutros tempos quando eu fui botar uma cerca... é interessante, eu achei uma panela de ferro, mas não tinha tampa e nem alça, era velha! Era panela velha de ferro, dei a um colega para fazer solda, não prestava para coisa nenhuma. Pense... chinês não ia misturar petróleo com panela velha, não combina.

Acharam, também, acrescenta José,

[U]ma peça de cerâmica, meio goiavada [côncava, convexa], não é certinha como essas de colocar em piso. Não se sabe se é um pote, uma panela, um vaso, mas não conseguiram coisa de valor (moedas e ouro), "cavucaram" [escavaram] no lugar uns seis buracos, mas nada encontraram. Ficou só no esforço, quem sabe tinha pote de moeda, os antigos enterravam dinheiro.

\section{Produz assombro... pelo fogo que corre}

"O que eu vejo por a... no campo," disse Lucas,

\begin{abstract}
é uma luzinha verde, verde que passa, corre de um lado para o outro. Eu temei em "garrar" [apanhar], mas quando peguei... não tinha nada na mão, sumiu e apareceu lá no alto e foi sumindo, desaparecendo, sem deixar sinal... Faz uns três anos que não vejo mais, ela se escondeu! Ou, quem sabe, foi embora
\end{abstract}

\footnotetext{
${ }^{5} \mathrm{O}$ interlocutor se refere ao invasores portugueses que chegaram ao Acre e subjugaram os povos indígenas, produzindo genocídio e etnocídio.
} 
Rindo Lucas que estava na conversa, disse: "parece assombração" e, na sequência afiançou, "eu não tenho medo, há muito assombro de gente e de animal por aqui, mas é preciso saber viver e respeitar."

Nas oficinas, os pesquisadores procuraram junto com estudantes e professores ilustrar as histórias narradas pelos conhecedores do lugar. Os "assombros" podem ser vistos a partir da modelagem e elas se misturam com as influências do mundo, hoje! Portanto, ela pode não corresponder diretamente ao que é narrado pelos interlocutores. É preciso compreender que quem narra, não necessariamente modela; e quem modela o "assombro", talvez, não foi assombrado.

Geralda chega, e entrando na roda com simpatia, acrescenta: as luzes "saem de um geoglifos para outro, a gente consegue seguir, faz barulho quando passa, penso que podem ser pessoas!" Informou que, aparece, também, "uma tocha de fogo que fica focando e depois desaparece, a gente não vê quem segura o objeto. Quando chega o verão as luzes se tornam frequentes, aparecem muito, "a gente tem medo, pois não é avião rasgando o céu. O fogo corre que corre."

Fernanda, uma jovem estudante, informa que os desenhos no solo eram "da parte [pertenciam] dos índios que faziam sacrifícios, eles vieram do Peru para o Brasil, essa era a teoria da minha avó."

Maria escutava em silêncio, mas com as observações feitas por Fernanda, narrou: "há pessoas que comentam é gente de outro planeta a assombrar. Eu não acredito! É gente daqui, desse mundo, embora se veja a luz como se fosse uma "navezinha", uma tocha rodando." Alguns, segundo Maria, dizem que é imaginação, mas "não é não!" Disse que perto de sua casa "tem um cemitério", no qual foram achados crânio e ossos, pois "no tempo dos seringais" se enterravam mortos, sem "precisar" de cemitério" e para marcar o local do enterramento, era comum afixar no local, objetos como garrafas e pedaços de madeira, às vezes em forma de cruz.

"Acaba que a conversa não deixa de ser um mistério, nada foi provado! Mas, os antigos gostam de lembrar e contar. Onde, há enterramento há luz! Morto não mete medo, só vivo, desses eu fico longe", complementou Maria.

Nossa jovem narradora, indicou algo importante: quem conta a história, na maior parte das vezes, crê no que diz e o fato de alguém dizer que é imaginação não altera a convicção do contador de histórias, pois ele "viu".

E, para concluir as observações da roda de conversa, Henrique "especulou que sendo local de enterramento, um cemitério indígena, há assombro! E, "os índios não 
enterravam os seus mortos em terra alheia, buscavam um lugar especial." $E$ colocando mais ênfase afirma: "não ter visto esqueletos ou ossadas" nos geoglifos que conhece. Mas, "pode ser" que ainda se encontre. Afinal, não ver ossadas, hoje, não muda o fato de que mortos podem sempre assombrar os vivos e em qualquer cemitério aqui ou alhures, há histórias de assombrações e visagens!

\section{Podem ser venatórios [lugares de caça]?}

As "valetas" podem ser proteção dos índios que moraram no lugar e servem para evitar ataques e perseguições de inimigos, porque, contou o senhor João, "os índios antigos gostavam de dividir os grupos," mas não se sabe se tem disso no Brasil, diz ficar intrigado de ser no Acre.

Entre as observações feitas pelo interlocutor, algumas hipóteses foram apresentadas para explicar os geoglifos. Diz nosso narrador que "as valas podem ser armadilhas ou depósito de caça, de alimentos," e refletindo retruca: "não há instrumentos para caçadas no interior das "valetas" e, tão pouco, se encontrou restos de animais fruto de excursões venatórias [caçadas]."

Durante as oficinas realizadas nas escolas, os estudantes eram convidados a visitar e "experimentar" o Tequinho, quando brincam "medindo o geoglifo" com seus corpos, mostrando as ondulações no terreno. Antes de dar início às oficinas, estudantes e professores, presentes às escolas, foram visitar o Tequinho. Não se levou os pequeninos, com menos de sete anos, por razões de segurança, estes ficavam em atividades na escola acompanhados pelos professores que regiam as turmas e pelos pesquisadores que "inventavam" atividades nas quais eles pudessem contar historinhas.

$\mathrm{Na}$ volta "do campo" os estudantes discutiam o que viram e expressavam suas opiniões oralmente, muitas das quais constam deste texto, e eram chamados a registrá-las em desenhos e modelagens. O resultado foi produtivo.

Os professores das classes mais avançadas - trabalhou-se com ensino fundamental e médio - reuniram-se com os pesquisadores para pensar e refletir sobre atividades que tivessem os geoglifos como referências. Muitas foram as sugestões, algumas das quais são apresentadas em vários momentos.

\section{São colombinos [do tempo de Colombo]...}


Da mesma forma que alguns moradores das imediações dos espaços que contém geoglifos falaram sobre a versão cabralina, outros "defenderam" que, os espaços referentes aos geoglifos, passaram a existir com Cristóvão Colombo, o genovês, que em nome da Coroa espanhola, invadiu o continente Americano, um pouco antes de Cabral.

Relata Miguel, que os espanhóis percorreram o continente, abrindo picadas caminhos estreitos, em geral abertos à mão - e, na passagem, pelos lugares os invasores "cavucavam [abriam buracos] com ferramentas especiais," pois deveriam colocar os chamados "marcos de salamão" ou "marcos de Salomão", ou ainda, "marcos de Salamanca", insígnia dos reis espanhóis, fabricados com sete metros de ouro e que eram "desmontáveis". Cada índio escravizado, que acompanhava o explorador, carregava um pedaço do marco a ser afixado na terra, auxiliando o invasor a tomar posse dos territórios indígenas, sem anuência de quem quer que seja.

Miguel afirma que foram fincados inúmeros marcos "por aí... ," na PanAmazônia, mas quem pode ter certeza, ele interroga. E, continuando a narrativa, informa que os mais velhos dizem que há no Acre, no Amazonas e até na Bolívia. Mas, ele não encontrou nenhum marco, acha que alguém pegou antes de dele e deu risada.

\section{Lugares de quarentena?}

José, informou que jamais viu os geoglifos. Entretanto, ouviu falar que era o lugar dos índios colocarem doentes, acometidos de "malárias", pois precisavam ser afastados para não contaminar os demais. Lá, os doentes permaneciam por até 40 dias. O lugar era seco e "confortável" aos doentes, pois não apanhava sol direto e não entrava água. Mas, ele acredita que "vala" não é lugar de colocar pessoas doentes, embora constate que há muita malária no Acre.

\section{Abrigos na disputa entre bolivianos e nordestinos}

$\mathrm{Na}$ escola, a professora Glória, relatou que os moradores dizem que os geoglifos foram produzidos pelos bolivianos por conta da guerra contra os nordestinos.

Entretanto, ela acredita que antes do "Acre ser Acre" os Maias, os Astecas e os Incas viviam no local e como eles eram politeístas produziram os espaços desenhados com terra para as práticas sagradas compreendendo cultos e rituais. Provavelmente, 
reuniam muitas aldeias para os ritos sagrados e é possível que alguns espaços fossem usados como cemitérios.

Prossegue Glória, com a chegada dos espanhóis, os povos foram para o Peru e a Bolívia, com o passar dos tempos chegaram os nordestinos para trabalhar no corte da borracha. Por conta da disputa pela borracha, os nordestinos avançaram para o território boliviano e deu-se a guerra Brasil contra a Bolívia. O Brasil conquistou o Acre na disputa, mas os povos indígenas levaram a pior, sofreram drástico processo de depopulação por conta do genocídio. Hoje, no Acre, há povos indígenas de origem linguística Pano e Aruak que resistem bravamente ao etnocídio. As "valetas" foram usadas em momento de disputa.

Laura, também, professora entra na discussão e informa que como os geoglifos foram "desenhados" há muito tempo, as formas só vieram à tona com o desmatamento das florestas acreanas. E, afirma "não se sabe o que "realmente" aconteceu no passado é preciso investigar e, olhando fixamente aos pesquisadores, disse: contem pra nós quando descobrirem. E, uma das pesquisadoras brincando respondeu: "as histórias fazem parte do conhecimento e ajudam os arqueólogos a desvendar o novelo de mistérios."

\section{É possível serem armazéns d’água?}

Uma última tese foi levantada por Georgina. "Ouvi falar que os geoglifos podiam ser uma forma de armazenar água para a plantação da lavoura." E informa que sua avó, conta que "à noite, no silêncio da solidão é possível escutar as águas passado nos subterrâneos dos geoglifos" e, com ar de reflexão continuou, "vai ver que os povos passados construíam os geoglifos, com valetas bem fundas, para tirar água do subsolo de forma protegida, pois assim tinham água armazenada - e, a qualquer momento - para beber, irrigar a lavoura e usar no cotidiano." E Georgina vai fundo na reflexão, informa à plateia que acreditava que é por essa razão que "há, sempre, uma nascente de água limpa, encostadinha ao imenso desenho de terra."

$\mathrm{Na}$ sequência, Juarez informa que tudo deve ter sido construído tendo como ferramentas "pedras de raio de trovão", além de declarar a existência de "catacumbas com pedaços de vasos", pois sua avó conta os casos há muito tempo. Ele com convicção afirmou: "esses sítios [arqueológicos] são marca registrada de povos indígenas que viveram há milhares de anos. As marcas nos geoglifos foram gravadas para deixar os costumes e as tradições registradas para transmitir toda a sua história 
às crianças e assim sucessivamente." E finaliza, "eles [os geoglifos] são como pessoas a contar as tradições, nós é que não sabemos ler." Talvez, as histórias nos assustem, disse nosso pequeno analista, porque as pessoas do passado, ainda procuram uma forma de nos contar, daí o assombro ..." Talvez, ainda, "cuidem da água" para não faltar no futuro. E, assim, Juarez deixou os demais estudantes pensativos.

\section{A Arqueologia e as "certezas"...}

As histórias que a comunidade conhece são importantes para os estudiosos da Antropologia, pois nenhum trabalho se faz, adequadamente, sem a colaboração da comunidade, especialmente, aquilo que se chama Arqueologia Comunitária, pois ela só se realiza com a colaboração de todos, como vimos nas linhas anteriores.

No caso do geoglifo do Tequinho a interação começou quando os arqueólogos, ainda tentavam localizar os sítios arqueológicos para estudá-los. A equipe de pesquisa precisa perguntar pelos sítios para poder encontrá-los, pois mesmo usando mapas e o Sistema de Posicionamento Global (GPS, na sigla em inglês) as informações dos moradores são importantes, pois eles conhecem os lugares pela vivência.

$\mathrm{Na}$ tentativa de obter êxito é preciso falar a língua da comunidade. E, com os acreanos nativos ou "adotados" - porque migrantes vindos de outras plagas, aprendeu-se que os geoglifos são conhecidos como: valas ou valetas, pelos que tiveram chance de conhecer as formas; outros indicam serem buracos, no meio do pasto ou da floresta, os quais são especiais; outros chamam as movimentações de terra de fosso; e, a grande maioria, dos moradores se refere aos espaços como trincheiras ou, ainda, trincheiras de guerra em alusão ao conflito Brasil/Bolívia.

Localizados os sítios arqueológicos, ou sejam, os lugares nos quais as estruturas remanescentes permanecem como testemunho reveladores da história da ocupação humana na região, o próximo passo é estabelecer boas relações com os donos dos terrenos e com as demais pessoas, pois a equipe contrata trabalhadores locais para auxiliá-los nas tarefas de escavação dos recintos que cercados por enormes fossos, apresentam formatos geométricos, "bem desenhados" com movimentação de grandes áreas de terra.

As construções remanescentes foram projetadas e executadas pelos povos indígenas que habitavam, o hoje, estado do Acre. As estruturas foram datadas, pelos arqueólogos, como tendo idade entre 3.000 e 1.000 anos antes do momento presente 
(SCHAAN, PARSSINEN \& RANZI, 2008). O que encanta e desafia os que conhecem os geoglifos.

Os trabalhos em Arqueologia requerem do pesquisador e seus auxiliares parcimônia, pois é preciso "pesquisar sem produzir danos", e requer observar cada detalhe do espaço, recolha de artefatos, em geral fragmentos de objetos antigos, pedaços, muitas vezes, diminutos que se conservam "intactos" e permitem "reconstituir" o passado, indicando de forma mais completa possível para que o espaço era usado e pela análise do material quem foi o construtor, como fez e como usava.

Chamo atenção para o fato de que o senhor Joaquim, ao contar sua história, indica procedimentos muito semelhantes aos dos arqueólogos, sendo que no caso dos arqueólogos todo cuidado é pouco e os objetos retirados do local devem ser guardados e tratados adequadamente. Aos arqueólogos não é permitido "doar" os objetos a terceiros ou tê-los em seu poder, pois os artefatos, os vestígios ósseos e tudo o mais que for encontrado é patrimônio público.

Nossa obrigação, enquanto cidadão é revelar às autoridades que trabalham com o patrimônio, nas secretarias de educação e cultura, e nos departamentos de patrimônios de diversas fundações os "achados", assim eles podem ser estudados e preservados.

Os arqueólogos podem coletar, examinar e analisar os vestígios, mas não tem como ouvir as histórias das pessoas que produziram o material em outras épocas. 0 que é uma pena, mas podem "especular" a partir das histórias registradas e das histórias que ouvem em campo. O trabalho arqueológico é feito considerando os achados e as possibilidades que o contexto e os artefatos permitem inferir.

Uma "pergunta que não quer calar" é onde entram as histórias contadas pelos moradores atuais dos sítios arqueológicos e de seu entorno?

Tentaremos responder, aqui, retomando as histórias ouvidas. Cada teoria/tese apresentada, pelos moradores do lugar, sobre os usos dos geoglifos que podem auxiliar na formulação de hipóteses (de conjecturas e especulações controladas) a respeito das construções e de como os espaços eram usados nos tempos antigos.

Vamos pensar em cada formulação e compreender como a vivência produz experiência e, como os experientes, especialmente, os mais velhos ao reproduzirem 
as histórias "fazem ciência" concretamente. ${ }^{6}$ Assim, no quadro abaixo resumimos as histórias contadas e nomeamos as teorias/teses apresentadas para desenvolver a importância das mesmas para melhor compreensão do fazer "ciência em concreto."

Quadro 1: Teorias/teses nativas sobre os Geoglifos.

\begin{tabular}{|c|c|c|}
\hline Identificação & Argumentos & Importância \\
\hline $\begin{array}{l}\text { Engenheiros } \\
\text { construtores do } \\
\text { passado }\end{array}$ & $\begin{array}{c}\text { Os povos indígenas na região eram } \\
\text { exímios construtores e construíam } \\
\text { monumentos a partir da } \\
\text { movimentação de grandes } \\
\text { quantidades de terra. }\end{array}$ & $\begin{array}{c}\text { Diferenciar fenômenos } \\
\text { naturais de } \\
\text { construção cultural. } \\
\text { Identificar as } \\
\text { formações com fruto } \\
\text { de trabalho humano. } \\
\text { Considerar e valorizar } \\
\text { os conhecimentos de } \\
\text { povos etnicamente } \\
\text { diferenciados. }\end{array}$ \\
\hline Cabralina & $\begin{array}{c}\text { As construções foram executadas } \\
\text { antes da chegada dos invasores } \\
\text { europeus e os autores foram os } \\
\text { povos indígenas. }\end{array}$ & $\begin{array}{l}\text { Compreender que } \\
\text { foram produzidos, } \\
\text { antes da chegada dos } \\
\text { invasores europeus. } \\
\text { Admitir a presença de } \\
\text { povos indígenas. }\end{array}$ \\
\hline Chinesa & $\begin{array}{l}\text { Atribui a construção aos chineses } \\
\text { interessados em petróleo, } \\
\text { provavelmente pela rixa que os } \\
\text { acreanos mantêm com os bolivianos } \\
\text { desde os tempos dos "soldados da } \\
\text { borracha". }\end{array}$ & $\begin{array}{l}\text { Indicar a possibilidade } \\
\text { de ser criação de } \\
\text { estrangeiros. }\end{array}$ \\
\hline $\begin{array}{l}\text { Fogo que } \\
\text { assombra }\end{array}$ & $\begin{array}{l}\text { Apontam a área como tendo sido } \\
\text { utilizada como cemitério e por essa } \\
\text { razão é um lugar que assombra. }\end{array}$ & $\begin{array}{c}\text { Equiparar os } \\
\text { cemitérios indígenas } \\
\text { aos cemitérios de } \\
\text { outros povos. }\end{array}$ \\
\hline Venatórios & $\begin{array}{l}\text { Indicam a área como tendo sido } \\
\text { utilizada para guarda e } \\
\text { armazenamento de caça e/ou outros } \\
\text { alimentos. }\end{array}$ & $\begin{array}{c}\text { Referir a abundância } \\
\text { oferecida pela floresta } \\
\text { amazônica antes do } \\
\text { desmatamento. }\end{array}$ \\
\hline $\begin{array}{c}\text { Colombina ou } \\
\text { Colombiana }\end{array}$ & $\begin{array}{l}\text { Atribuem à construção a chegada do } \\
\text { colonizador sem eliminar a } \\
\text { participação de povos indígenas. }\end{array}$ & $\begin{array}{l}\text { Informar a presença } \\
\text { de povos indígenas } \\
\text { escravizados na área. }\end{array}$ \\
\hline
\end{tabular}

\footnotetext{
${ }^{6}$ A formulação "ciência do concreto" foi desenvolvida pelo antropólogo Claude Lévi-Strauss para indicar que os povos etnicamente diferenciados, como os povos indígenas no Brasil produzem conhecimentos que acumulados, constituem o acervo de saberes e integram a cultura dos povos. O conhecimento é passado de geração em geração e são suporte de estabelecimento das sociedades no mundo em que vivem. Aqui, empresto a ideia, mas prefiro denominar de ciência em concreto para imprimir movimento ao conceito e apontar que os conhecimentos tradicionais são dinâmicos, modificam-se ao longo do tempo e, também, que os povos são abertos a novos conhecimentos e que ao interagirem com pessoas de outras sociedades, aproveitam e incorporam o que, na sua visão de mundo, é válido. Conferir: (LÉVI-STRAUSS, 1997).
} 


\begin{tabular}{|c|c|c|}
\hline $\begin{array}{l}\text { Lazaretos de } \\
\text { quarentena }\end{array}$ & $\begin{array}{c}\text { Indicam os saberes de atenção a } \\
\text { saúde, quando em alguns momentos } \\
\text { se requer a existência de } \\
\text { confinamentos. }\end{array}$ & $\begin{array}{l}\text { Mostrar o } \\
\text { conhecimento dos } \\
\text { povos indígenas a } \\
\text { respeito da } \\
\text { preservação da } \\
\text { saúde. }\end{array}$ \\
\hline $\begin{array}{c}\text { Trincheiras de } \\
\text { guerra }\end{array}$ & $\begin{array}{l}\text { Admite a estratégia dos moradores } \\
\text { antigos (povos indígenas e migrantes) } \\
\text { para proteção e defesa do território. }\end{array}$ & $\begin{array}{l}\text { Apresentar os povos } \\
\text { indígenas e migrantes } \\
\text { como estrategistas em } \\
\text { tempos de guerra. }\end{array}$ \\
\hline $\begin{array}{l}\text { Armazéns } \\
\text { d'água }\end{array}$ & $\begin{array}{l}\text { Indicam a área como tendo sido } \\
\text { utilizada para guarda e } \\
\text { armazenamento de água para uso } \\
\text { variados inclusive na irrigação da } \\
\text { lavoura. }\end{array}$ & $\begin{array}{l}\text { Indicar os sistemas } \\
\text { indígenas de } \\
\text { armazenamento } \\
\text { d'água e irrigação } \\
\text { dentro da floresta } \\
\text { tropical, admitindo a } \\
\text { existência de longos } \\
\text { períodos de estiagem. }\end{array}$ \\
\hline
\end{tabular}

É possível admitir algumas das possibilidades indicadas pelas histórias como plausíveis, pois pelo fato de serem histórias trazem elementos importantes da vida cotidiana à discussão. E, como conjecturas, são boas para pensar na Arqueologia.

Vejam o que está nas entrelinhas das teorias/teses nativas.

1. Os geoglifos foram construídos por seres humanos.

2. O território acreano foi habitado no passado por pessoas que se revelaram bons construtores.

3. Os desenhos de terra podem ter tido usos diversos de acordo com o povo e as necessidades no terreno (no contexto da floresta).

4. Eram povos etnicamente diferenciados, povos indígenas (incas, astecas, maias, pano, aruak entre outros) ou migrantes (nordestinos, bolivianos, europeus).

5. Quem quer que tenha construído renovou ou revolucionou as formas de armazenar alimentos e água e de proteção e defesa dos territórios.

6. O que quer que os geoglifos sejam precisam ser preservados, pois integram o patrimônio acreano.

As entrelinhas são importantes e indicam estratégias culturais interessantíssimas e que valorizam povos que construíram o Acre preservando-o para o Brasil.

\section{Com as mãos na massa}


Evidentemente, as histórias aqui apresentadas poderão ser ampliadas com outras colaborações, afinal reescrever a história dos primeiros habitantes do território identificado como sendo área dos geoglifo é crucial, inclusive, incorporando a história contada pelos próprios povos indígenas pertencentes às etnias que sobreviveram à exploração e dizimação provocada pelo processo de colonização. Escrever a história a partir de fontes, até então pouco incorporadas por arqueólogos e historiadores, é tarefa que apreende toda a dinâmica do processo histórico, sabemos quem deu origem aos geoglifos, como eles são pensados pelos moradores e que tipo de ações podem ser desenvolvidas a partir de sua preservação patrimonial.

Como disse a professora Eliana:

[...] é preciso trabalhar com o depoimento das pessoas que hoje habitam essas localidades [os sítios arqueológicos] oferecendo oportunidade de produzir uma mudança de mentalidade no sentido de preservar a área dos geoglifos para melhor aceitação da musealização.

Trabalhar a elaboração de uma "nova história" dos povos no Acre é o desafio! Os professores ficaram interessados em ensinar a desenhar e projetar, como referiu 0 professor Adriano, a partir dos geoglifos, nas aulas de desenho, ciências e matemática, pois os resultados da visão multidisciplinar poderiam ser maquetes que agreguem o conhecimento de todos e, quem sabe, produzir um produto que informado por historinhas divulguem os geoglifos. Adriano ensinou que a maquete pode ser feita em vários tamanhos e as miniaturas seriam lembranças que os visitantes poderiam carregar consigo, acompanhada de um conto de uma historinha dessas que a comunidade sabe cotar tão bem.

Adriano possui visão avançada, vê o ensino aliado ao fazer, à produção de bens. Quem sabe das maquetes outras ideias não vão "brotar" para fazer crescer o cuidado com os geoglifos.

Para concretizar a ideia de Adriano, Deolinda sugeriu incentivar os estudantes a produzir relatos, contos, histórias em quadrinhos, poemas e canções para divulgar os geoglifos, assim quando os incrédulos visitantes chegarem ao Tequinho podem ser brindados com produtos da tradição acreana. Deolinda sonha alto, ela imagina apresentação de música e saraus (reuniões) de poesia no espaço dos geoglifos, e animada prossegue: "pode ter um palco?" ao que um dos pesquisadores respondeu: "... desde que não abale a estrutura dos geoglifos e a presença de pessoas não comprometa o sossego dos moradores." 
Sérgio pensou em usar os sofisticados cálculos dos construtores dos geoglifos em suas aulas de matemática. Trabalhar as formas geométricas no terreno, mostrando na prática o uso das formas geométricas, inclusive seu uso de réguas, fitas métricas como as que conhecemos hoje. $\mathrm{E}$ daí, os problemas dentro das matemáticas poderiam se contextualizados e mais interessantes aos estudantes.

Maurício que ensina geografia pensou em usar os geoglifos nas aulas em que trabalhe solo, relevo, interferências na paisagem entre muitos outros temas.

Como o leitor pode ver, as ideias estão fervilhando é só usar e acrescer possibilidades, pois os geoglifos são "bons pra pensar"!

\section{Referências}

Documentos

- Registros impressos (textos, desenhos e fotografias) e orais (relados gravados, oficinas e filmagens) relativas ao Projeto de Musealização do Geoglífos Tequinho Arqueologia comunitária no Acre.

\section{Bibliografia}

BEZERRA, Márcia. 'As moedas dos índios': um estudo de caso sobre os significados do patrimônio arqueológico para os moradores da Vila de Joanes, ilha de Marajó, Brasil. Boletim do Museu Paraense Emílio Goeldi. Ciências Humanas, v. 6(1), p. 57-70, 2011.

CABRAL, Mariana Petry. De cacos, pedras moles e outras marcas: percursos de uma arqueologia não-qualificada. Amazônica, Revista de Antropologia, v. 6, n. 2, p. 314$331,2014$.

CABRAL, Mariana Petry; SALDANHA, João Darcy de Moura. Um sítio, múltiplas interpretações: o caso do chamado 'Stonehenge do Amapá'. Arqueologia Pública, v. 3, p. 7-13, 2008.

CHOQUE QUISPE, María Eugenia. Principios para la construción de una democracia intercultural. In: ZAPATA SILVA, Claudia (Ed.). Intelectuales indígenas piensan América Latina. Quito: Simon Bolivar/Abya-Yala, 2007. p.273-282.

DUNNELL, R. C. The Notion Site. In: ROSSIGNOL, J. e WANDSNIDE, L. (Ed.). Space, Time, and Archaeological Landscapes. New York: Plenum Press, 1992. p.21-42.

FERNANDES, Glenda Consuelo Bittencourt. "Um buraco no meio da praça": múltiplas percepções sobre um sítio arqueológico em contexto urbano amazônico - o caso de Belém, Pará. 2014. 177 Dissertação (Mestrado). PósGraduação em Antropologia, Universidade Federal do Pará, Belém. 
FERREIRA, Lúcio Meneses. Sob fogo cruzado: Arqueologia Comunitária e Patrimônio Cultural. Revista de Arqueologia Pública, v. 3, p. 81-92, 2008.

GOMES, Raimundo Ney Cruz; LOPES, Rhuan Carlos dos Santos. Cacareco de índio e artefato arqueológico: conversas entre arqueólogos e a família Souza no sítio Cedro, Santarém - Pará. Arqueologia Pública, v. 5, p. 20-31, 2012.

HODDER, lan. Interpretación en Arqueología. Corrientes actuales. Barcelona: Crítica, 1994.

JACQUES, Clarisse Callegari. Os sentidos da cultura material no cotidiano e na memória das famílias da comunidade quilombola de Cinco Chagas do Matapi. Revista de Arqueologia Pública, v. 8, p. 7-21, 2013.

LEITE, Lúcio Flávio Siqueira Costa. 'Pedaços de pote', 'bonecos de barro' e 'encantados' em Laranjal do Maracá, Mazagão - Amapá: Perspectivas para uma Arqueologia Pública na Amazônia. 2014. 154 Dissertação (Mestrado). Programa de Pós-Graduação em Antropologia, Universidade Federal do Pará, Belém.

LÉVI-STRAUSS, Claude. O pensamento selvagem. Campinas, SP: 1997.

MORAES, Irislane Pereira de. Do tempo dos pretos d'antes aos povos do Aproaga: patrimônio arqueológico e territorialidade quilombola no vale do rio Capim (PA). 2012. 237 Dissertação (Mestrado). Programa de Pós-Graduação em Antropologia, Universidade Federal do Pará, Belém.

SCHAAN, Denise Pahl. Paisagens da Amazônia Ocidental. In: SCHAAN, D. P.;RANZI, A., et al (Ed.). Geoglifos, paisagens da Amazônia Ocidental. Rio Branco: GKNoronha, 2010. p.13-17.

inédito, 2011.

Arqueologia e Multivocalidade: Desafios Contemporâneos. v. Manuscrito

SCHAAN, Denise Pahl; MARQUES, Fernando Luis Tavares. Por que não um filho de Joanes? Arqueologia e comunidades locais em Joanes, Ilha de Marajó. Revista de Arqueologia, v. 25, n. 1, p. 106-123, 2012.

SCHAAN, Denise Pahl; PARSSINEN, Martti; RANZI, Alceu. Arqueologia da Amazônia Ocidental: os Geoglifos do Acre. Belém: EDUFPA, Biblioteca da Floresta Ministra Marina Silva, 2008.

SCHAAN, Denise Pahl; PÄRSSINEN, Martti; RANZI, Alceu; PICCOLI, Jacó César. Geoglifos da Amazônia ocidental: Evidência de complexidade social entre povos da terra firme. Revista de Arqueologia, v. 20, p. 67-82, 2007. 